\title{
ANALISIS KERAGAAN EKONOMI USAHA PENANGKAPAN IKAN KAPAL MOTOR DI TANJUNG LUAR, LOMBOK TIMUR
}

\author{
Hulaifi \\ Jurusan Biologi Universitas Terbuka \\ e-mail: hulaifi@ecampus.ut.ac.id
}

\begin{abstract}
Economic diversity is a detailed description of fishery business that conducted by an individual or business entity to get some profit by analyzing economically and financially as well as the stability of fishing effort against natural risks and the dynamics of economic also technical change of business. The purpose of this research is to analyze the economic diversity of fishing effort by fisherman who using motor boats in Tanjung Luar, East Lombok, West Nusa Tenggara. The data analysis conducted in the form of analysis economic diversity of fishing business using motor boats. The parameters of economic analysis of the fishing effort business using 3 main criteria and 2 additional criteria. The 3 main criteria are Net Present Value (NPV), Internal Rate of Return (IRR), Net Benefit/Cost Ratio (NB/CR). While 2 additional criteria are Payback Period (PP), and Profitability Ratio (PR). The result of this research is fishing business based on the result of economic diversity criteria such as (NPV, IRR, Net B / C Ratio, Profitability Ratio and Payback Period) and the financing sensitivity of fishing vessels by boat is still feasible to be developed, then to obtain optimal benefits the fishermen are expected to increase the size of boats, technology, professional human resources and the addition of machine power used, so that fishermen can operate properly in the waters ZEE is further and deeper. The recommendation from the above fishing effort also need support from other aspect such as legality aspect, fishery fish farming, technical policy from local government and optimum condition at various allocations.
\end{abstract}

Keywords: diversity, economy, fishing

\begin{abstract}
ABSTRAK
Keragaan ekonomi merupakan suatu gambaran secara detail usaha perikanan, yang dilakukan oleh perorangan atau badan usaha untuk mencari keuntungan, dengan menganalisis secara ekonomi dan finansial, serta kestabilan usaha penangkapan ikan tersebut terhadap risiko alam dan kedinamisan perubahan ekonomi dan teknis usaha. Tujuan dari penelitian ini yakni menganalisis keragaan ekonomi usaha penangkapan ikan oleh nelayan kapal motor Tanjung Luar Kabupaten Lombok Timur. Analisis data yang dilakukan berupa analisis keragaan ekonomi usaha penangkapan ikan pada kapal motor. Parameter analisis keragaan ekonomi usaha penangkapan ikan menggunakan 3 kriteria utama dan 2 kriteria tambahan, ketiga kriteria utama investasi tersebut adalah Net Present Value (NPV), Internal Rate of Return (IRR), Net Benefit/Cost Ratio (N B/C R), sedangkan 2 kriteria tambahan adalah Payback Period (PP) dan Profitability Ratio (PR). Hasil dari penelitian ini yakni usaha penangkapan ikan berdasarkan hasil kriteria keragaan ekonomi seperti (NPV, IRR, net B/C ratio, profitability ratio dan payback period) dan sensitivitas usaha secara finansial, usaha penangkapan ikan oleh nelayan kapal motor masih layak
\end{abstract}


dikembangkan, dan untuk mendapatkan keuntungan yang optimal, maka nelayan diharapkan untuk menambah ukuran kapal, teknologi, SDM yang profesional dan penambahan kekuatan mesin yang dipergunakan, agar nelayan dapat beroperasi dengan layak di perairan ZEE yang lebih jauh dan lebih dalam. Rekomendasi dari kegiatan upaya penangkapan tersebut di atas, perlu dukungan dari aspek lainnya seperti aspek legalitas, tataniaga ikan yang menguntungkan nelayan, kebijakan teknis dari pemerintah setempat serta tercapainya kondisi optimum pada berbagai alokasi.

Kata kunci: keragaan, ekonomi, penangkapan ikan

Sumberdaya kelautan sudah selayaknya dijadikan tumpuan harapan bangsa di masa depan, mengingat sumberdaya perikanan yang berada di perairan Indonesia seluas 5,8 juta $\mathrm{km}^{2}$ memiliki potensi perikanan sebanyak 6,4 juta ton/tahun dengan tingkat pemanfaatan sebesar $59 \%$. Jumlah potensi tersebut yang merupakan potensi di perairan Zona Ekonomi Ekslusif (ZEE) sebanyak 2,3 juta ton. Jumlah tersebut terdiri dari berbagai jenis ikan, seperti ikan pelagis besar sekitar 975,05 ribu ton/tahun; ikan pelagis kecil sebesar 3,23 juta ton (52,54\%), ikan demersal 1,8 juta ton $(28,96 \%)$ dan ikan karang 0,97 juta ton $(15,81 \%)$. Potensi sumberdaya perikanan yang besar tersebut dapat dimanfaatkan untuk meningkatkan kesejahteraan masyarakat tetapi potensi tersebut belum dioptimalkan. Dengan potensi demikian, Indonesia memiliki peranan penting dalam perikanan dunia karena dari sekitar 17 wilayah penangkapan ikan dunia, bangsa kita menguasai 9 wilayah penangkapan dan lebih dari $10 \%$ dari total potensi ikan yang ada di dunia. Kesembilan wilayah yang dikuasai Indonesia adalah Selat Malaka, Laut Cina Selatan, Laut Jawa, Selat Makasar dan Laut Flores, Laut Banda, Laut Seram sampai Teluk Tomini, Laut Sulawesi dan Samudera Pasifik, Laut Arafura serta Samudera Indonesia (DKP RI, 2004).

Dari segi potensi wilayah, PPI Tanjung Luar Kabupaten Lombok Timur relatif kecil dibandingkan wilayah lain. Dalam lima tahun terakhir (2006-2010) fluktuasi jumlah tangkapan total ikan di perairan Selat Alas rata-rata sebesar 2,87\% per tahun, yaitu dari 3.807.191 ton pada tahun 2000 menjadi 5.039.446 ton pada tahun 2010 (DKP Prov. NTB 2011).

Armada penangkapan perikanan di daerah ini sangat banyak yakni sebanyak 4.777 armada pada tahun 2010, peningkatan ini disebabkan oleh pertambahan jumlah penduduk yang cukup tinggi dan selama ini sektor perikanan kebanyakan merupakan lahan pekerjaan yang fleksibel dalam menampung pengangguran yang semakin tinggi. Sumber daya ikan yang ada di Selat Alas merupakan salah satu sumber daya alam di Nusa Tenggara Barat yang memberikan kontribusi penting bagi paling tidak 21.902 orang nelayan yang beroperasi di perairan ini (DKP Prov. NTB, 2011).

Usaha penangkapan ikan merupakan bentuk kegiatan ekonomi, dimana faktor keuntungan adalah tujuan akhir. Keuntungan pada usaha penangkapan ikan dilakukan dengan meningkatkan produksi jenis ikan yang menjadi tujuan penangkapan. Peningkatan produksi hasil tangkapan menunjukkan meningkatnya intensitas atau frekuensi penangkapan terhadap sumberdaya ikan yang menjadi tujuan penangkapan. Peningkatan intensitas penangkapan ikan akan memberikan dampak positif dan negatif, positifnya adalah adanya peningkatan produksi yang dapat memberikan keuntungan, sedangkan dampak negatifnya adalah apabila intensitas penangkapan yang dilakukan tidak seimbang dengan potensi sumberdaya ikan, akan terjadi pengurangan stok dan pada akhirnya akan terjadi penurunan produksi hasil tangkapan (Hulaifi, 2011). 
Keragaan ekonomi adalah gambaran secara detail usaha perikanan, yang dilakukan oleh perorangan/badan usaha untuk mencari keuntungan, dengan menganalisis secara ekonomi dan finansial, serta kestabilan usaha tersebut terhadap risiko alam dan kedinamisan perubahan ekonomi dan teknis usaha, seperti turun naiknya produksi, biaya operasional usaha penangkapan, penerimaan, serta harga produksi. Menurut Fauzi (2010), analisis keragaan ekonomi perikanan dilakukan dengan menggunakan data hasil survey dari industri penangkapan ikan kemudian dirinci berdasarkan komponen biaya yang dikeluarkan oleh industri tersebut.

Beberapa faktor yang dapat menjadi penyebab masih rendahnya tingkat pendapatan nelayan, antara lain alat tangkap yang tidak produktif, keterbatasan sumberdaya, keterbatasan modal untuk pengembangan usaha, dan lain-lain. Semua faktor ini dapat mempengaruhi penurunan produktivitas. Secara tidak langsung dengan produktivitas yang rendah, maka keuntungan yang didapatkan nelayan pun berkurang. Oleh karena itu, semua faktor yang berperan dalam peningkatan produksi perlu dioptimalkan pemanfaataannya. Khusus bagi unit penangkapan kapal motor, faktorfaktor produksi yang dapat mempengaruhi hasil tangkapan perlu diketahui agar dapat dilakukan efisiensi dan efektivitas terhadap faktor-faktor input guna menghasilkan output optimal. Dengan demikian, pada akhirnya diharapkan dapat meningkatkan pendapatan nelayan sehingga kesejahteraannya juga meningkat.

Jumlah nelayan yang melebihi kapasitas dapat menimbulkan kemiskinan, kapasitas (modal, teknologi, dan akses informasi) yang berbeda antar nelayan dapat menimbulkan konflik. Untuk menekan terjadinya kondisi yang tidak diharapkan, maka sumber daya ini perlu segera dikelola dengan tepat. Tetapi sampai saat ini, informasi keberadaan sumber daya ikan di perairan Selat Alas, khususnya informasi yang berupa hasil kajian ilmiah, masih sangat terbatas (Karnan, 2012).

Berdasarkan uraian yang telah dijelaskan, perlu untuk dilakukan analisis lebih mendalam mengenai usaha penangkapan ikan, dengan tujuan untuk menganalisis faktor-faktor penentu dan variabel-variabel yang mempengaruhi keragaan usaha penangkapan ikan oleh nelayan yang mengunakan kapal motor yang ada di Tanjung Luar, Kabupaten Lombok Timur.

\section{METODE}

Data yang digunakan yakni data primer dan data sekunder. Data primer diperoleh dengan mengadakan observasi langsung ke lokasi penelitian dan melakukan wawancara dengan pemilik kapal (juragan), nakhoda (fishing master) dan anak buah kapal (ABK) dengan menggunakan kuesioner. Satuan penelitian adalah unit penangkapan ikan kapal motor yang beroperasi di Tanjung Luar, Kabupaten Lombok Timur. Data primer ini mencakup data unit penangkapan, fishing base, fishing ground, metode penangkapan ikan, data produksi dan faktor-faktor produksi kapal, harga ikan hasil tangkapan dan data finansial usaha.

Data sekunder yang diperlukan adalah data berkala (time series) hasil tangkapan dan upaya penangkapan kapal kapal motor yang menangkap ikan di Kabupaten Lombok Timur selama 5 (lima) tahun terakhir (2011-2015). Data ini diperoleh dari laporan tahunan PPI Tanjung Luar, Dinas Kelautan dan Perikanan, Kabupaten Lombok Timur.

Pengumpulan data untuk analisis kelayakan finansial usaha penangkapan dan usaha penangkapan ditentukan berdasarkan kriteria Gross Benefit/Cost Ratio (B/C ratio), Net Present Value (NPV) dan Internal Rate of Return (IRR) (Kadariah, 1999). Untuk melihat titik balik modal atau keuntungan sama dengan nol dilakukan analisis titik impas Profitability Ratio (PR) (Riyanto, 1995). Untuk mengetahui lama waktu (periode) pengembalian modal, maka didekati dengan analisis pay back of period (PP) (Soekartawi, 1995). 
Analisis data yang dilakukan dalam penelitian ini adalah analisis keragaan ekonomi usaha penangkapan ikan pada kapal motor. Parameter analisis keragaan ekonomi usaha penangkapan ikan menggunakan perhitungan Net Benefit Cost Ratio (Net B/C), Net Present Value (NPV), Internal Rate of Return (IRR), Profitability Ratio (PR) dan Pay back of Period (PP). Dengan batasan-batasan potensi sumberdaya ikan yang terdapat di daerah penelitian, dihitung berdasarkan hasil tangkapan pada kapal motor yang beroperasi di Tanjung Luar Kabupaten Lombok Timur dan Analisis keragaan finansial usaha dihitung berdasarkan harga rata-rata ikan hasil tangkapan dan rata-rata biaya yang dikeluarkan oleh unit penangkapan kapal motor per trip (satu kali melaut).

Untuk mempertajam hasil usaha maupun peramalan benefit-cost dimasa kini dan mendatang, maka disertakan analisis sensitivitas berdasarkan beberapa kondisi yang memungkinkan bisa terjadi di lapang. Adapun skenario kondisi yang diperkirakan adalah kenaikan biaya operasional penangkapan $10 \%$ dan 20\%, Penurunan penerimaan dari penjualan hasil tangkapan $10 \%$ dan $20 \%$, dan penurunan produksi hasil tangkapan $10 \%$ dan $20 \%$. Analisis finansial dilakukan dengan beberapa asumsi, dengan maksud meminimalisasi dan mengeliminasi penyimpangan dari beberapa komponen analisis, agar proyeksi benefit dan cost pada saat ini dan mendatang, yang dipresent value-kan tetap relevan dengan waktu sekarang (present time), dimana analisis finansial sedang dibuat.

\section{HASIL DAN PEMBAHASAN}

Analisis keragaan usaha penangkapan ikan yang dijalankan oleh nelayan Tanjung Luar Lombok Timur meliputi beberapa aspek ekonomis penangkapan ikan yang dipertimbangkan dalam penelitian ini adalah investasi, biaya tetap (fixed cost) dan biaya tidak tetap (variable cost). Untuk menilai kelayakan finansial usaha penangkapan didasarkan pada 3 (tiga) kriteria utama investasi tersebut adalah Net Present Value (NPV), Internal Rate of Return (IRR), Net Benefit/Cost Ratio (N B/C R), sedangkan 2 (dua) kriteria tambahan adalah Payback Period (PP) dan Profitability Ratio $(\mathrm{PR})$.

Nilai investasi yang diperoleh menunjukkan besarnya modal yang diperlukan untuk mengoperasikan satu unit armada. Berdasar hal ini, maka optimalisasi armada dalam menangkap ikan sangat diperlukan agar jangka waktu pengembalian modal dapat lebih cepat. Rata-rata modal yang berasal dari milik pribadi berdasarkan wawancara dengan pemilik usaha adalah sebesar $10 \%$ dari investasi, sisanya merupakan pinjaman dari bank. Kriteria investasi adalah suatu indeks untuk mengukur dan membandingkan tingkat keuntungan, dari berbagai usaha perikanan, sehingga dapat dinilai apakah usaha tersebut menguntungkan (layak) atau tidak layak, serta memberikan suatu urutan (usulan-usulan investasi) menurut tingkat keuntungan masing-masing. Dana yang terbatas, perlu dibuat ranking, dengan berbagai kriteria/indeks agar dapat mengalokasikan dana tersebut untuk memaksimumkan keuntungan (Fauzi, 2011).

Biaya tetap dalam usaha penangkapan ikan meliputi biaya operasional dan biaya penyusutan, yang selanjutnya dinamakan biaya penangkapan. Biaya ini tidak mengalami perubahan dengan berubahnya volume produksi. Biaya penyusutan merupakan pengalokasian biaya investasi suatu unit usaha setiap tahun sepanjang umur ekonomis unit usaha tersebut. Biaya penyusutan ini tidak mengandung unsur pengeluaran uang tetapi berhubungan dengan faktor depresi modal akibat bertambahnya umur unit usaha penangkapan.

Biaya tidak tetap dalam usaha penangkapan ikan di Tanjung Luar adalah biaya perawatan, retribusi dan upah $\mathrm{ABK}$. Biaya ini sifatnya berubah dan tergantung pada volume produksi. Biaya usaha penangkapan adalah besarnya rata-rata nilai input yang dikeluarkan oleh nelayan pada setiap 
trip penangkapan ikan setelah dikalikan dengan harga satuan input (Saprani, Mahyudin dan Agusliani, 2016).

Pada kegiatan usaha penangkapan ikan kapal motor oleh nelayan di Tanjung Luar, membutuhkan beberapa biaya yang harus di keluarkan seperti biaya pengoperasian yang dibagi dalam biaya tetap (fixed cost) dan biaya variabel (variabel cost). Biaya tetap adalah seluruh biaya yang dikeluarkan dalam jumlah yang tetap untuk sekali melakukan operasional penangkapan, sedangkan biaya tidak tetap adalah semua biaya yang dikeluarkan dalam jumlah yang tidak tetap setiap melakukan operasi penangkapan. Biaya ini terdiri atas biaya perawatan, retribusi dan upah ABK. Upah ABK bersifat tidak tetap dalam jumlah tetapi bersifat tetap dalam sistem bagi hasil. Jadi berdasarkan asumsi tersebut, biaya operasional penangkapan ikan yakni total pengeluaran rata-rata per unit penangkapan ikan, yang meliputi biaya operasional dan biaya penyusutan per trip penangkapan.

Biaya operasional penangkapan per trip oleh nelyan kapal motor di Tanjung Luar yakni Rp. 2.653.000 dengan rincian pengeluaran terbesar yakni pada pembelian solar sebesar Rp. 1.125.000. Pengadaan es balok sebesar Rp. 450.000, selanjutnya pembelian oli sebesar Rp. 100.000 biaya pembelian air tawar sebesar Rp. 30.000 dan kebutuhan kosumsi selama waktu penangkapan sebesar Rp. 900.000 . Sehingga alokasi biaya pengoperasian lebih banyak terpakai untuk pembelian solar sebagai bahan bakar utama yang dipakai untuk mengoperasikan kapal motor di Tanjung Luar. Hal ini mendorong nelayan di lokasi penelitian harus meningkatkan hasil tangkapan untuk mengimbangi biaya operasional yang meningkat.

Rata-rata nelayan melakukan operasi penangkapan hampir setiap bulan dengan rata-rata upaya penangkapan 2 trip per bulan dan hampir sepanjang tahun nelayan melakukan penangkapan. Dari hasil perhitungan diketahui bahwa rata-rata biaya operasional yang dikeluarkan per upaya penangkapan per tahun sebesar Rp 134.835.426 dan per tripnya sebesar Rp. 4.782.836. Harga ratarata hasil tangkapan selama periode tahun 2011-2015 setiap tahunnya sebesar Rp 10.370 per kg.

Pendapatan rata-rata nelayan per trip pada umumnya berkisar antara Rp. 2.235 .280 sampai Rp. 6.168.686 per trip atau rata-rata responden sebesar Rp. 3.812.233 dengan pendapatan nelayan pertahun berkisar antara Rp. 33.529.193 sampai Rp. 102.863.661. Menurut Karnan (2012), kegiatan perikanan tangkap termasuk dalam aktivitas ekonomi. Karena itu, keuntungan yang setinggitingginya yang diperoleh dari kegiatan ini merupakan target yang dituju.

Biaya penangkapan kapal motor dapat dilihat pada Tabel 1. Tabel tersebut menunjukkan bahwa biaya yang terbesar dikeluarkan adalah pada biaya operasional kemudian disusul upah ABK.

Dengan meningkatnya upaya penangkapan, maka biaya operasional yang dikeluarkan juga bertambah besar sehingga mempengaruhi penerimaan. Total penerimaan diperoleh dengan mengalikan hasil tangkapan per tahun dengan harga ikan per satuan berat, sedangkan total biaya penangkapan diperoleh dari total pengeluaran per unit penangkapan per trip per tahun. Rente ekonomi perikanan merupakan selisih antara total penerimaan dengan total biaya penangkapan pada setiap kondisi pengelolaan (rata-rata aktual) (Hulaifi, 2011).

Analisis finansial berkaitan dengan aspek ekonomis dari usaha yang dijalankan. Aspek ekonomis kapal motor yang dipertimbangkan dalam penelitian ini adalah investasi, biaya tetap (fixed cost) dan biaya tidak tetap (variable cost). Untuk menilai kelayakan finansial usaha perikanan kapal motor didasarkan pada kriteria Net Present Value (NPV), Internal Rate of Return (IRR) dan Gross Benefit/Cost Ratio (B/C ratio), sedangkan 2 kriteria tambahan adalah Payback Period (PP) dan Profitability Ratio (PR). Kriteria investasi adalah suatu indeks untuk mengukur dan membandingkan tingkat keuntungan, dari berbagai usaha perikanan, sehingga dapat dinilai apakah usaha tersebut 
menguntungkan (layak) atau tidak layak, serta memberikan suatu urutan (usulan-usulan investasi) menurut tingkat keuntungan masing-masing.

Tabel.1. Rincian Biaya Rata-Rata Penangkapan Ikan Oleh Nelayan Kapal Motor di Tanjung Luar Kabupaten Lombok Timur Tahun 2011-2015

\begin{tabular}{lc}
\hline Uraian Jenis Biaya & Jumlah Biaya (Rp/thn) \\
\hline Biaya Penyusutan & 16.395 .426 \\
Biaya Perawatan & 14.750 .000 \\
Biaya Operasional & 53.060 .000 \\
Biaya Restribusi & 5.900 .000 \\
Upah ABK & 44.730 .000 \\
\hline Total Biaya & 134.835 .426 \\
Jumlah Trip & 24 \\
Biaya total Per Trip & 4.782 .836 \\
\hline
\end{tabular}

Sumber: PPI Tanjung Luar (diolah, 2016)

Salah satu pertimbangan awal untuk melakukan suatu usaha adalah besarnya nilai uang yang diperlukan untuk mendirikan usaha tersebut. Investasi adalah biaya yang dikeluarkan untuk membangun dan menjalankan suatu usaha. Investasi untuk pengoperasian kapal motor dapat dilihat pada Tabel 2.

Tabel 2. Biaya Investasi Kapal Motor yang Dioperasikan di Tanjung Luar

\begin{tabular}{lrrr}
\hline \multicolumn{1}{c}{ Komponen Alat } & $\begin{array}{c}\text { Jumlah } \\
\text { (Unit) }\end{array}$ & \multicolumn{1}{c}{$\begin{array}{c}\text { Harga } \\
\text { (Rp.) }\end{array}$} & \multicolumn{1}{c}{$\begin{array}{c}\text { Jumlah } \\
\text { (Rp.) }\end{array}$} \\
\hline Kapal & 1 & 45.000 .000 & 45.000 .000 \\
Mesin & 1 & 20.000 .000 & 20.000 .000 \\
Box Penampung lkan & 3 & 3.500 .000 & 10.500 .000 \\
Pompa Air & 1 & 1.250 .000 & 1.250 .000 \\
Selang (Meter) & 20 & 17.000 & 340.000 \\
Tali (Meter) & 100 & 30.000 & 3.000 .000 \\
Generator dan lampu & 1 & 5.000 .000 & 5.000 .000 \\
GPS Type 12 & 1 & 2.500 .000 & 2.500 .000 \\
Kompas & 1 & 150.000 & 150.000 \\
Jangkar & 1 & 400.000 & 400.000 \\
Terpal & 1 & 100.000 & 100.000 \\
Pancing Besar & 100 & 8.500 & 850.000 \\
Pancing Kecil & 30 & 6.500 & 195.000 \\
Umpan (Plastik lkan) & 1 & 10.000 & 10.000 \\
Bandolan & 20 & 12.000 & 240.000 \\
\hline \multicolumn{1}{c}{ Jumlah } & & & 89.535 .000 \\
\hline
\end{tabular}

Sumber: PPI Tanjung Luar (diolah, 2016)

Rata-rata jumlah uang yang diperlukan sebagai investasi dalam pengoperasian kapal motor sebesar Rp. 89.535.000 (Tabel 2). Biaya yang paling besar adalah untuk pengalokasian kapal sebanyak Rp. 45.000 .000 dan mesin Rp 20.000.000, sedangkan terkecil adalah pada penyediaan 
umpan sebesar Rp. 10.000. Nilai investasi yang diperoleh menunjukkan besarnya modal yang diperlukan untuk mengoperasikan satu unit kapal motor di Tanjung Luar. Berdasar hal ini, maka optimalisasi armada dalam menangkap ikan sangat diperlukan agar jangka waktu pengembalian modal dapat lebih cepat. Rata-rata modal yang berasal dari milik pribadi berdasarkan wawancara dengan pemilik usaha adalah sebesar $10 \%$ dari investasi ( \pm Rp. 10.000 .000$)$, sisanya merupakan pinjaman dari bank.

Pada usaha penangkapan ikan di laut, modal investasi yang harus dimiliki oleh pengusaha atau pemilik usaha perikanan tangkap sebagai sarana utama untuk kelancaran produksinya, dapat dikelompokkan dalam tiga kelompok yaitu perahu, alat tangkap, mesin dan peralatan pendukung yang lain (Jayanto, 2013). Biaya pengoperasian kapal motor dibagi dalam biaya tetap (fixed cost) dan biaya variabel (variabel cost). Biaya tetap yang dimaksudkan dalam penelitian ini adalah seluruh biaya yang dikeluarkan dalam jumlah yang tetap untuk sekali melakukan operasional armada kapal motor. Biaya tidak tetap adalah semua biaya yang dikeluarkan dalam jumlah yang tidak tetap setiap melakukan operasi penangkapan armada kapal motor. Biaya ini terdiri atas biaya perawatan, retribusi dan upah ABK. Upah ABK bersifat tidak tetap dalam jumlah tetapi bersifat tetap dalam sistem bagi hasil.

Biaya tetap pengoperasian kapal motor meliputi biaya operasional dan biaya penyusutan, yang selanjutnya dinamakan biaya penangkapan. Biaya ini tidak mengalami perubahan dengan berubahnya volume produksi. Biaya operasional kapal motor meliputi pengeluaran untuk solar, es balok, oli, minyak tanah, konsumsi (beras, rokok, gula dan kopi), air tawar. Biaya penyusutan merupakan pengalokasian biaya investasi suatu unit usaha setiap tahun sepanjang umur ekonomis unit usaha tersebut. Biaya penyusutan ini tidak mengandung unsur pengeluaran uang tetapi berhubungan dengan faktor depresi modal akibat bertambahnya umur unit usaha. Biaya ini diperoleh dengan membagi besarnya nilai investasi suatu komponen alat dengan daya tahannya. Pada biaya perawatan untuk setiap unit penangkapan kapal motor dilakukan 2 (dua) bulan sekali terhadap seluruh komponen alat tangkap. Perawatan yang dilakukan berupa pengecatan, perbaikan dan penggantian komponen alat yang rusak.

Biaya tidak tetap dalam pengoperasian kapal motor adalah biaya perawatan, retribusi dan upah ABK. Biaya ini bersifat berubah dan tergantung pada volume produksi. Perincian biaya tetap dan biaya tidak tetap pengoperasian kapal motor disajikan pada Tabel 3.

Tabel 3. Rata-rata Biaya Tetap dan Biaya Tidak Tetap Per Tahun yang Dikeluarkan Oleh Kapal Motor yang Beroperasikan di Tanjung Luar.

\begin{tabular}{lc}
\hline Komponen Biaya & Biaya per tahun (Rp/thn) \\
\hline Biaya Tetap & \\
Operasional & 53.060 .000 \\
Penyusutan & 16.395 .426 \\
\hline Sub Total & 69.455 .426 \\
\hline Biaya Tidak Tetap : & \\
Perawatan & 14.750 .000 \\
Restribusi & 5.900 .000 \\
Upah ABK & 44.730 .000 \\
\hline Sub Total & 65.380 .000 \\
\hline Total & 134.835 .426
\end{tabular}

Sumber: PPI Tanjung Luar (diolah, 2016) 
Berdasarkan Tabel 3, total biaya per tahun yang dikeluarkan untuk pengoperasian kapal motor di Tanjung Luar sebesar Rp. 134.835.426 dengan perincian biaya tetap Rp. 69.455.426 dan biaya tidak tetap Rp. 65.380 .000 . Biaya tetap dalam hal ini adalah biaya penangkapan yang telah dijelaskan sebelumnya.

Retribusi yang berlaku di Tanjung Luar ditetapkan sebesar $2 \%$ yang terdiri atas 0,5\% untuk desa dan 1,5\% untuk PPI, restribusi diambil dari hasil penjualan per trip penangkapan. Rata-rata biaya retribusi per tahun yang dikeluarkan setiap unit penangkapan kapal motor adalah Rp.

5.900.000 atau sebesar Rp. 295.000 per trip. Upah ABK diperoleh setelah dikeluarkan biaya retribusi dan operasional dan dibagi $50 \%$ dengan pemilik kapal. Pembagian upah antara ABK sendiri bervariasi, tergantung pada jabatannya di atas kapal. Juru mudi sekaligus sebagai fishing master mendapat 2 (dua) bagian dari upah ABK, sedangkan juru mudi dan setiap ABK lainnya mendapat 1 bagian. Juru mudi mendapatkan bagian yang lebih besar karena keberhasilan operasi penangkapan dan keselamatan pelayaran menjadi tanggung jawabnya. Setiap kapal rata-rata memiliki 5 orang ABK. Berdasarkan hasil pengamatan dan wawancara dengan Anak Buah Kapal (ABK) kapal motor di daerah penelitian, penerimaan yang didapat belum mampu meningkatkan kesejahteraannya secara layak. Hal ini disebabkan karena pengelolaan penerimaan yang kurang tepat.

Hasil perhitungan analisis kelayakan finansial usaha kapal motor berdasarkan kriteria Net Present Value (NPV), Internal Rate of Return (IRR), Benefit Cost Ratio (BC Ratio), Pay Back of Period (PP)) dan Profitability Ratio (PR) dapat dilihat pada Tabel 4.

Tabel 4. Nilai-nilai pada Berbagai Perubahan Kondisi Keragaan Ekonomi

\begin{tabular}{lrrrrr}
\hline \multirow{2}{*}{ Kondisi } & \multicolumn{5}{c}{ Keragaan Ekonomi } \\
\cline { 2 - 6 } & NPV & $\begin{array}{r}\text { IRR } \\
(\%)\end{array}$ & $\begin{array}{c}\text { Net } \\
\text { BCR }\end{array}$ & PR & PP \\
\hline Awal & 53.156 .880 & 27 & 1,18 & 2,07 & 3,08 \\
Biaya Naik 10\% & 16.684 .431 & 19 & 1,18 & 1,36 & 4,24 \\
Biaya Naik 20\% & -19.788 .019 & 7 & 0,81 & 0,93 & 6,20 \\
Penerimaan Kas Turun 10\% & 11.368 .743 & 17 & 1,13 & 1,31 & 4,41 \\
Penerimaan Kas Turun 20\% & -30.419 .395 & 0,1 & 0,64 & 0,74 & 7,77 \\
Biaya Naik 10\% Penerimaan Turun 10\% & -25.103 .707 & 3 & 0,73 & 0,85 & 6,83 \\
Produksi Turun 10\% & -41.156 .726 & 0,7 & 0,52 & 1,31 & 9,67 \\
Produksi Turun 20\% & -77.108 .700 & -14 & 0,10 & 0,74 & 52,39 \\
Biaya Naik 10\% Produksi Turun 10\% & -13.431 .380 & 8 & 0,86 & 0,00 & 5,84 \\
\hline
\end{tabular}

Sumber: PPI Tanjung Luar (diolah, 2016)

Net Present Value (NPV), Usaha penangkapan ikan, yang dilakukan oleh nelayan kapal motor di Tanjung Luar dan sekitarnya yang diproyeksikan dalam lima tahun (2011-2015), dengan mengunakan nilai proceeds dan kisaran suku bungga bank yang berlaku pada saat penelitian $5 \%$, menghasilkan rataan benefit terdiskonto Rp.33.411.598 per tahun, memberikan NPV sebesar Rp. 53.156.880, berarti selama usaha penangkapan digeluti oleh nelayan kapal motor di daerah Tanjung Luar ini, akan diperoleh akumulasi keuntungan bersih dimasa mendatang dengan nilai sekarang (hingga usaha selesai) sebesar NPV tersebut. Sehingga usaha ini layak dikembangkan ( $g 0$ ), karena memenuhi kriteria NPV>1. Sedangkan jika produksi turun sekitar $20 \%$, usaha penangkapan ikan sudah tidak layak untuk diteruskan, karena memenuhi kriteria NPV $<0$. 
Internal Rate of Return (IRR), menunjukkan kemampuan modal yang telah dikeluarkan pada usaha penangkapan ikan untuk memberikan benefit dalam bentuk tingkat diskonto, dengan kriteria IRR > OCC (opportunity cost of capital). IRR paling tinggi sebesar $27 \%$ pada usaha penangkapan dengan kapal motor, artinya modal investasi yang ditanamkan dalam usaha ini mampu memberikan keuntungan diskonto 27\%, (lebih besar dari tingkat diskonto lembaga perbankan 5\%). Dengan demikian usaha ini lebih layak dilanjutkan (go). Sedangkan IRR < OCC terjadi jika sensitivitas pada penerimaan kas turun $20 \%$ IRR-nya $0,1 \%$, sedangkan jika biaya naik $10 \%$ IRR-nya $19 \%$, selanjutnya jika penerimaan turun 10\% IRR-nya $17 \%$ dan jika produksi turun $10 \%$, dengan nilai IRRnya sebesar $7 \%$, atau jika produksi turun sebanyak $20 \%$ maka IRR-nya sebesar $-4 \%$ dengan demikian usaha penangkapan pada posisi produksi turun sampai $10 \%$ atau $20 \%$ usaha ini tidak layak lagi dilanjutkan.

Net Benefit Cost Ratio (N-BCR), merupakan perbandingan antara net benefit, dengan biaya investasi yang telah dipresent-value-kan selama usaha ini berlangsung, dengan kriteria NBCR $>1$, maka usaha ini harus dikembangkan. Selama umur usaha penangkapan berlangsung akan memberikan net benefit, rasio antara keduanya paling tinggi adalah 1,18 kali. Hal ini berarti bahwa keuntungan yang diperoleh dari usaha ini 1,18 kali, terhadap total biaya investasi yang dikeluarkan, sehingga secara keseluruhan usaha penangkapan ikan berdasarkan NBCR layak diteruskan.

Analisis sensitivitas menunjukkan, jika terjadi perubahan kondisi ekonomi akan berdampak pada penurunan kinerja ekonomi usaha tersebut, berupa terdepresiasinya nilai NBCR sehingga $<1$, dengan demikian usaha ini tidak layak lagi untuk dijalankan, mengingat hasil yang akan diterima tidak akan mampu menutupi nilai biaya investasi yang telah dikeluarkan, seperti yang terjadi jika mengalami penerimaan kas turun $20 \%$ rasionya 0,64 kali, sedangkan jika biaya naik $10 \%$ dengan rasio 1,18 kali, selanjutnya jika penerimaan turun 10\% akan menghasilkan rasio 1,13 kali dan jika produksi turun $10 \%$, dengan rasio sebesar 0,52 kali $(<1)$, dengan demikian usaha ini tidak layak lagi dilanjutkan.

Profitability Ratio (PR), merupakan perbandingan antara total benefit dengan total modal yang telah dikeluarkan. Kriterianya adalah $\mathrm{PR}>1$, maka usaha layak dijalankan. Hasil analisa usaha penangkapan ikan di wilayah ini mampu memberikan nilai PR yang cukup besar $(2,07)$, artinya keuntungan yang diperoleh selama usaha berlangsung sebesar 2,07 kali biaya kapital yang telah dikeluarkan, sehingga layak untuk diteruskan. Analisis sensitivitas menunjukkan, bahwa jika terjadi perubahan kondisi ekonomi, akan berdampak pada relatif kecilnya nilai PR yang diperoleh. Nilai PR paling stabil yaitu jika penerimaan kas turun $20 \%$, pada kondisi penerimaan nilai rasio keuntungannya 0,74 , artinya stagnan atau zero profit $(\mathrm{PR}=1)$ sedangkan jika produksi turun $20 \%$ dan biaya naik $10 \%$ produksi turun $10 \%$, akan mengalami penurunan nilai rasio $\mathrm{PR}<1$ masing-masing sebesar 0,74 dan 0,00 kali.

Payback Period adalah jangka waktu pengembalian biaya investasi. Kriteria kelayakan dipilih dari masa pengembalian investasi yang tercepat, dengan asumsi bahwa modal investasi yang telah dikembalikan tersebut dapat ditanam lagi dalam usaha, sehingga mampu meningkatkan nilai keuntungan/benefit hingga usaha berakhir, keuntungan modal investasi dapat digunakan untuk aktivitas ekonomi lain yang lebih produktif dan menguntungkan.

Usaha penangkapan ikan dengan mengunakan kapal motor di daerah Tanjung Luar ini memberikan masa pengembalian investasi yang relatif cepat ( 3 tahun 8 minggu) yaitu $1 / 2$ umur usaha, sehingga layak untuk dilaksanakan. Berdasarkan analisis sensitivitas, jika usaha penangkapan ini sangat peka terhadap semua kondisi perubahan ekonomi yang disimulasikan, akibat salah satu faktor besarnya biaya investasi yang dikeluarkan, sedangkan benefit present value relatif kecil, maka 
selisih keduanya tidak terlalu besar. Nilai payback period (PP) paling lama adalah apabila produksi turun $20 \%$ yakni pengembalian modal investasi relatif lama, dengan artian melebihi umur usaha.

Berdasarkan kriteria utama (NPV, IRR dan NBCR) dan kriteria tambahan (payback period \& PR) dan simulasi sensitivitas tersebut, maka usaha penangkapan ikan dengan mengunakan kapal motor di perairan Tanjung Luar dan sekitarnya, layak untuk dilanjutkan dan dikembangkan, dengan catatan kondisi perubahan ekonomi fluktuasinya tidak ekstrim yang dapat berdampak buruk pada keberlanjutan usaha. Rekomendasi dari kegiatan upaya penangkapan tersebut, perlu dukungan dari aspek lainnya seperti aspek legalitas, tataniaga ikan yang menguntungkan nelayan, kebijakan teknis dari pemerintah setempat serta tercapainya kondisi optimum pada berbagai alokasi. Sensitivitas kelayakan finansial yang menggambarkan kepekaan usaha ini terhadap berbagai perubahan dan dinamika usaha yang pasti terjadi dalam usaha perikanan, perlu dipertimbangkan bagi pengembangan kegiatan perikanan ikan ke depan, mengingat labilnya suatu usaha terhadap faktor luar seperti naiknya harga bahan bakar solar yang dapat menjadikan labilnya usaha.

Jumlah dan jenis alat tangkap yang dioperasikan di suatu perairan sangat berpengaruh terhadap laju elsploitasi sumber daya ikan di perairan tersebut. Untuk keberlanjutan pengusahaan terhadap suatu sumber daya ikan, jenis alat tangkap yang digunakan harus mempertimbangkan aspek teknis, finansial, lingkungan, dan sosial (Karnan, Husni dan Santoso, 2011).

Untuk mengoptimalkan pemanfaatan sumberdaya di suatu perairan, maka konsep yang harus dikembangkan adalah konsep pengelolaan atau kepemilikan tunggal, dimana stok ikan di wilayah perairan tertentu dianggap model oleh pemilik tunggal (single owner). Pemilik tunggal dapat diwakili oleh pemerintah daerah atau instansi lainnya. Tujuan yang ingin dicapai oleh pemilik tunggal adalah memaksimalkan nilai sekarang (present value) dari keuntungan bersih kegiataan pemanfaatan sumberdaya perikanan sepanjang waktu.

Pengendalian secara ekonomi menggunakan perubah ekonomi sebagai instrumen pengendalian upaya penangkapan ikan. Perubah ekonomi yang relevan dalam menunjang pemanfaatan sumberdaya perikanan yang optimal meliputi: harga ikan, subsidi BBM, pajak dan biaya izin penangkapan ikan, pengembangan alternatif lapangan kerja nelayan, pemberian kredit, pengembangan prasarana pelabuhan perikanan, peningkatan keterampilan nelayan dan pengembangan agribisnis perikanan.

\section{SIMPULAN}

Berdasarkan hasil kriteria keragaan ekonomi (NPV, IRR, net B/C ratio, profitability ratio dan payback period) dan sensitivitas usaha secara finansial, usaha penangkapan ikan oleh kapal motor masih layak dikembangkan. Kecuali jika sensitivitas pada penerimaan kas turun $20 \%$, biaya naik $10 \%$, penerimaan turun $10 \%$. Selain itu juga jika produksi turun $10 \%$, nilai usaha penangkapan ini tidak layak lagi dilanjutkan, dengan catatan kondisi perubahan ekonomi fluktuasinya tidak ekstrim yang dapat berdampak buruk pada keberlanjutan usaha. Sedangkan rekomendasi kegiatan usaha penangkapan ikan di tanjung luar, agar mendapatkan produksi yang optimal, maka ukuran kapal, teknologi, SDM yang profesional dan penambahan kekuatan mesin yang dipergunakan, supaya nelayan dapat beroperasi dengan layak di luar zona perairan ZEE.

\section{REFERENSI}

Departemen Kelautan dan Perikanan, RI. (2004). Laporan tahunan. Jakarta.

Dinas Kelautan dan Perikanan Propinsi Nusa Tenggara Barat. (2011). Statistik perikanan tangkap Nusa Tenggara Barat. Pemerintah Daerah Propinsi Nusa Tenggara Barat. 
Fauzi, A. (2010). Ekonomi perikanan (teori kebijakan dan pengelolaan). Jakarta: Gramedia Pustaka Utama.

Fauzi, A. (2011). Model pengelolaan perikanan tangkap di kawasan Selat Bali. Bogor: Sekolah Pascasarjana Institut Pertanian Bogor, Jawa Barat.

Hulaifi. (2011). Pendugaan potensi sumberdaya perikanan laut dan tingkat keragaan ekonomi penangkapan ikan (Kasus di PPI Sendang Biru, Kab. Malang), Jurnal matematika sains dan teknologi, Vol.12 No.2. 113-126.

Jayanto. (2013). Analisis produksi dan keragaan usaha garuk udang di perairan Kota Semarang. Jurnal saintek perikanan, Vol.8, No.2, 2013: 57-65, Undip. Semarang.

Kadariah. (1999). Evaluasi proyek. analisa ekonomis. Ed. Ke-2. Jakarta: LPFE UI.

Karnan, Husni, S., \& Santoso, D. (2011). Laporan survey perikanan desa nelayan di Kabupaten Sumbawa Barat dan Lombok Timur Nusa Tenggara Barat. Pusat Penelitian Pesisir dan Laut Universitas Mataram.

Karnan. (2012). Model pengelolaan perikanan tangkap di Selat Alas. NTB. Bogor: IPB

Riyanto, B. (1995). Dasar-dasar pembelanjaan perusahaan. Yogyakarta: BPFE.

Saprani, Mahyudin, I. \& Agusliani, E. (2016). Kajian program kegiatan penyediaan dan rehabilitasi sarana dan prasarana produksi perikanan tangkap terhadap peningkatan pendapatan nelayan di Kabupaten Tanah Laut Kalimantan Selatan. Jurnal enviro scienteae, Vol. 12 No. 2, Agustus 2016. 104-112.

Soekartawi. (1995). Dasar penyusunan evaluasi proyek. Jakarta: Penerbit Sinar Harapan. 